\title{
CLUSTER INTERNATIONALIZATION - A KEY COMPONENT FOR THE DEVELOPMENT AND COMPETITIVENESS OF CLUSTER MEMBERS
}

\begin{abstract}
Cluster internationalization can help businesses, especially small and medium enterprises (SMEs), to improve their competitiveness and accelerate their presence in global value chains. This point of view is often represented by cluster managers, researchers or politicians. However, the urgent need for internationalization of cluster enterprises is disproportionate to the state of understanding of the mechanisms and the effects arising from international cluster cooperation.

The first part of this article includes a review of the literature which aims to assess the state of knowledge on the internationalization of clusters and cluster enterprises. Importantly, a new cluster model has been presented - the so-called "born global" clusters, for which internationalization is the main strategy of development. The empirical part of the paper comprises the results of cluster benchmarking in Poland in 2014. Despite the fact that the results present internationalization as a key area of cluster development, further detailed analysis of the sub-indices expands this view. To conclude, the theme of cluster and cluster enterprise internationalization is relatively new and requires further research. The understanding of the determinants, the mechanisms and the effects of internationalization will allow to better fit cluster policy and management instruments at the level of regions as well as the European Union.
\end{abstract}

Keywords: cluster, management, strategy, internationalization, development, competitiveness

\section{INTRODUCTION}

The European economy is facing many challenges. These include, inter alia, the need to maintain an appropriate pace of development in relation to the Asian and American economies, to achieve a high degree of competitiveness of its own companies, mainly in the SME sector, as well as to meet the globalization processes, revealing the power of transnational corporations (TNC's). One way to answer these challenges is to increase the internationalization of enterprises. On the other hand, due to the nature and the potential of the above said small and medium-sized enterprises, it is believed that the best way for their foreign expansion is the internationalization of clusters.

The evolution of the importance of clusters internationalization can be seen within the M. Porter's approach ${ }^{3}$. In his first theoretical (conceptual) framework, he defines clusters

\footnotetext{
${ }^{1}$ Bogusław Bembenek, PhD, Faculty of Management, Rzeszow University of Technology, Poland - Rzeszow, e-mail: bogdanb@prz.edu.pl, autor korespondencyjny

${ }^{2}$ Marzena Frankowska, PhD, Faculty of Management and Economics of Services, University of Szczecin, Poland - Szczecin, e-mail: marzena.frankowska@wzieu.pl
} 
as "geographic concentrations of interconnected companies, specialized suppliers, service provider, firms in related industries, and associated institutions in particular fields that compete but also co-operate"4. The main advantage of clustering is essentially that geographic proximity facilitates networking between key drivers (rivalry and strategy, demand conditions, related and supporting industries and factor input conditions) and reduces the transactions costs imposed by distance. Then in his next work, M.E. Porter argues that globalized economic interactions mitigate disadvantages rather than create advantages. In his opinion distant sourcing is second-best solution compared to accessing a competitive local cluster in terms of productivity and innovation ${ }^{5}$. Given that globalization has changed and reduced the importance of traditional localized factors of production, it influenced Porter's opinion. In his more recent works he argues that it is primarily export oriented clusters that drive regional prosperity ${ }^{6}$, which manifests itself, inter alia, in paying higher wages than clusters serving purely local markets. While the earlier version of the cluster hypothesis had much in common with traditional agglomeration economy theory, this latest version of the cluster hypothesis has much in common with traditional export base theory. The export base clusters are important not just for their local supply-side characteristics but also because of their international demand-side linkages. From this perspective, export and trade bring external knowledge into innovation processes of a cluster and a region.

As shown above, the concept of cluster internationalization is a relatively new issue in economics. On the other hand, thorough the understanding of this phenomenon, it is not only urgent, but also important in the long term development of clusters and their competition on the international stage. Hence, a number of studies are conducted to gain better insight into the advancement of the internationalization processes in clusters, operating mechanisms and effects achieved at the level of cluster enterprises. The base of presented scientific considerations were the following research questions:

- how it should be understood the clusters internationalization?

- how clusters can increase the level of its internationalization?

- what are the benefits of internationalization for clusters and their members?

- to what extent Polish clusters are internationalized?

- what affects the degree of internationalization of Polish clusters?

Therefore, the key purpose of the article is to examine the importance of cluster internationalization in both theoretical aspects, and primarily, in relation to the results obtained by the clusters, illustrated with the example of the polish market in 2014. The

${ }^{3}$ J. Simmie, The contribution of clustering to innovation: from Porter I agglomeration to Porter II export base theories[in:] Handbook of Research on Innovation and Clusters. Cases and Policies, ed. Ch. Karlsson, Edward Elgar Publishing Ltd, Northampton 2008, p. 27.

${ }^{4}$ M.E. Porter, On Competition, Harvard Business School Press, Cambridge 1998, p. 197.

${ }^{5}$ Clusters represent a new way of thinking about national, state, and local economies, and they necessitate new roles for companies, for various levels of government, and for other institutions in enhancing competitiveness. It represent a kind of new spatial organizational form in between arm's-length markets on the one hand and hierarchies, or vertical integration, on the other. M.E. Porter, Location, competition and economic development: local clusters in a global economy, "Economic Development Quarterly", Vol. 14, No.1, February 2000, p. $15-34$.

${ }^{6}$ The performance of regional economies is strongly influenced by the strength of local clusters and the vitality and plurality of innovation.. M.E. Porter, The economic performance of regions, "Regional Studies", Vol.37, No. 6-7, August-October 2003, pp. 549-578. 
results of the study "Cluster Benchmarking in Poland - Edition 2014" carried out by the Polish Agency for Enterprise Development will be presented. Research methodology will be discussed in detail and the results will be interpreted in terms of internationalization. This is particularly important as the group of respondents included not only cluster managers, but also the cluster members.

\section{CLUSTER INTERNATIONALIZATION: THE NEED OR CHALLENGE?}

The development of clustering in EU is conducive to the creation of competitive, dynamic, knowledge-based economy, which is capable of permanent development, creates a larger number of workplaces and is characterized by social cohesion. Clusters consist of groups of independent and informally connected firms and institutions, capable of achieving operational efficiency and flexibility at the global level ${ }^{7}$. This new form of organization focuses on connections and interdependencies between the participants along the value added chain in the production, and innovations permanently stimulate investments and specialization ${ }^{8}$. Drawing on the research, M. Porter repeatedly indicates that there are four major examples of benefits that ensue from locating and running a business in a cluster environment, these are $^{9}$ :

- location within a cluster provides the firm with superior or lower costs access to specialized inputs, such as components, machinery, business services and personnel, compared to vertical integration;

- location within a cluster also provides a firm with superior access to all kinds of information (technical and/or marketing);

- cluster location can provide a firm (or a group of firms) with a number of "marketing complementarities," such as firm referrals, joint trade participation, and joint marketing delegations;

- cluster location often facilitates firm's access to institutions and public goods that otherwise would not be easy or cheap to access.

Only excellent clusters (which sometimes are also referred to as regional networks) that can compete and grow in the global economic environment can meet the expectations of policy makers and cluster stakeholders ${ }^{10}$. Therefore, contemporary clusters are forced to strengthen their competitiveness continuously, not only through internal but also external development. One of the possible ways within this scope is internationalization, which requires flexibility and efficiency in building relationships with foreign entities.

The fact that cluster internationalization becomes more and more significant ensues not only from the processes of globalization of the world economy and European Integra-

\footnotetext{
${ }^{7}$ M.E. Porter, Location, competition ..., op. cit., pp. 15-34; A.M. Kowalski, The role of innovative clusters in the process of internationalization of firms "Journal of Economics, Business and Management", Vol. 2, No. 3, 2014, p. 182.

${ }^{8} \mathrm{P}$. Strukelj, S. Dolinsek, Internationalization of $R \& D$ in two high-tech clusters and cooperation of $R \& D$ units in those clusters, "Journal of Industrial Engineering and Management", No. 3, Vol. 2, 2010, p. 299.

${ }^{9}$ M.E. Porter, Location, competition ..., op. cit., p. 19; D. Reid, R. DeMartino, S.C. Zyglidopoulos, The internationalization journey of a high-tech cluster, "Thunderbird International Business Review", Vol. 47 (5), 2005, p. 533.

${ }^{10}$ T. Lämmer-Gamp, G. Meier zuKöcker, T. Christensen, Clusters are individuals. Creating economic growth through cluster policies for cluster management excellence, The Danish Agency for Science Technology and Innovation, Copenhagen 2011, p.11.
} 
tion, including the changes concerning the conditions of transferring resources, liberalization of international trade and specialization of the value chains, but also from the fact that cluster structures constitute a successful means of attracting foreign investments. More and more frequently, foreign investors are interested in localizing their investments in industrial clusters, as they have a positive impact on the innovativeness of cluster members (e.g., enterprises) owing to the fact that heightened mobility of resources (principally people, capital, and information - including intellectual property), the development of durable relationships and new technologies in high-tech sectors are created by units located in close proximity to each other ${ }^{11}$. Gradual increase in the involvement of foreign entities in local or regional clusters can result in the valorisation of the available resources, knowledge diffusion, diversification of production and the development of supply chains, including the intensification of the development processes and cluster internationalization.

Cluster internationalization develops in quantitative and qualitative dimensions, inter alia, as a sign of "clustering of clusters". In theoretical approach, the notion of cluster internationalization is of interdisciplinary nature and, most frequently, is understood as:

- sequential and gradual involvement of a cluster in the activity on foreign markets, stable interaction of a broad spectrum of interrelated, interdependent, and mutually complementary stakeholders localized on a territory of two or more countries ${ }^{12}$;

- the creation and development of the network of relations with a wide group of entities, including the concentration of cluster activity on the work that is connected to its key competences and outsourcing the realization of the remaining functions and processes to the foreign partners ${ }^{13}$;

- the process of increasing cluster's involvement in international business activity, comprising active internationalization forms (export, FDI, capital and non-capital cooperation, networks) and passive ones (import, purchasing licenses, supplies for exporting companies, cooperation with foreign firms), the intensity, scope and forms of which depend on the adopted development strategy, including internationalization strategy ${ }^{14}$.

Presently, many researchers emphasize, that from the standpoint of the classical approach on the effects of globalization with regard to regional clusters, internationalization is seen as an exogenous factor that has a critical impact on the development and growth of the cluster (i.e. the organic cluster) at a certain stage of its life cycle ${ }^{15}$. According to A. S. Mikhaylov and A. A. Mikhaylova ${ }^{16}$, the internationalization is typical of the emergence phase of an international cluster, where concerted cluster policy is aimed at creating a globally oriented (i.e. born global) development strategy of regional institutions of two

\footnotetext{
${ }^{11}$ A.M. Kowalski, The role of innovative clusters ..., op. cit., p. 184.

12 A.S. Mikhaylov, A.A. Mikhaylova, Geographies of cluster internationalization: interorganizational linkages on the Baltica, "International Journal of Econometrics and Financial Management", Vol. 3, No. 1, 2015, p. 38.

13 A. Colovic, O. Lamotte, The role of formal industry clusters in the internationalization of new ventures, "European Business Review", Vol. 26, Issue 5, 2014, pp. 449-470.

${ }^{14}$ K. Przybylska, Proces internacjonalizacji przedsiębiorstwa w teorii ekonomicznej, Zeszyty Naukowe Wyższej Szkoły Ekonomicznej w Bochni, No. 3, 2005, p. 73

${ }^{15}$ P.H. Andersen, Regional clusters in a global world: production, relocation, innovation and industrial decline, "California Management Review", Vol. 49, Issue 1, 2006, pp. 101-122; A.S. Mikhaylov, A.A. Mikhaylova, Geographies of cluster ..., op. cit., pp. 32-37.

${ }^{16}$ A.S. Mikhaylov, A.A. Mikhaylova, Geographies of cluster ..., op. cit., p. 33.
} 
or more interacting countries in the framework of international cluster initiative (ICI). Clusters are subject to internationalization at two levels ${ }^{17}$ : the micro level (the level of firms taking part in clusters) and the meso level (the cluster as a whole) - through the actions undertaken by cluster coordinators, which work for establishing cooperation at the international level. Thus, cluster internationalization is of dual nature, as it occurs inside a cluster - at the level of behaviour of its particular members, and simultaneously it concerns the entire cluster, mainly due to the activity of the cluster coordinators (cluster organizations). Taking into consideration the active role of cluster organizations in the process of entering foreign markets, as well as the scope of passive internationalization, cluster internationalization can be achieved through, e.g. ${ }^{18}$ :

- the creation of formal and informal cooperation platforms, networks of relations between clusters and other foreign stakeholders,

- $\quad$ selective relocation, where particular cluster members move their business to other, foreign locations,

- the realization of common $\mathrm{R} \& \mathrm{D}$ projects within the scope of international consortium,

- common purchasing on foreign markets,

- the organization of common distribution channels on foreign markets,

- the cooperation with foreign partners (subcontracting).

For example, there are several different ways to classify the networks relevant to cluster internationalization ${ }^{19}$ : collaboration networks for cluster organizations e.g. European Cluster Managers Club, Europa Inter Cluster; collaboration networks for cluster policy makers e.g. European Cluster Alliance, The Competitiveness Institute; innovation networks for policy makers e.g. ERRIN, Eurada, Taftie; industry specific networks mainly for cluster organizations e.g. European Aerospace Cluster Partnership, European Automotive Strategy Network; geographically specific networks within Europe, e.g. BSR Stars (Baltic Sea Region), cluster group within EUSDR (European Strategy for the Danube Region); international networks outside Europe, e.g. EU-Japan, Euro-Med Innovation network, etc.

The increase in the scope of the internationalization of economy, markets and the supply base is accompanied by a systematic growth in the level of cluster internationalization. The observable changes within this scope are frequently perceived as a sign of logical consequence of pro-growth activities in this type of organizations. As far as the level of localization is concerned, all international clusters can be divided into two groups ${ }^{20}$ :

- the transnational cluster is an international cluster, the participants of which are concentrated as a rule in non-bordering regions of two or more countries; this cluster can comprise both a wide range of independent stakeholders and individual regional clusters;

\footnotetext{
${ }^{17}$ A.M. Kowalski, The role of innovative clusters ..., op. cit., p. 184.

${ }^{18}$ B. Jankowska, Internacjonalizacja klastrów, „Gospodarka Narodowa”, No. 5-6, 2010, p. 23.

${ }^{19} \mathrm{~B}$. Greenhalgh, Cluster internationalization handbook, Manchester Metropolitan University, Manchester 2012, p. 31.

${ }^{20}$ A. Mikhailov, Development of international clusters in the Baltic Sea Region, "Baltic Region", No. 1, Vol. 15, 2013 , p. 38.
} 
- a transboundary cluster is also an international cluster; however, its members are localized in the border regions of neighbouring countries.

However, what is crucial for the process of internationalization is that the decisionmakers who manage this organization strategically formulate a proper internationalization strategy. They also have to implement this plan efficiently, as to make the final level of internationalization appropriate to the current and future needs of a cluster. Internationalization strategy must be cohesive with the internationalization strategy of its members, mainly enterprises.

While characterising the strategy of the internationalization of cluster companies, $\mathrm{M}$. Gancarczyk emphasizes that whereas cost-oriented strategies assume the establishment of hierarchical relations, characterized by the subordination of the cooperants and one-way knowledge transfer, differentiation-oriented strategies assume the creation of heterarchical relations, which ensure the use and the development of knowledge ${ }^{21}$.

As any other economic process, the internationalization process involves certain risks and uncertainty, stimulated by the underestimation of the costs and the uncontrollable international environment ${ }^{22}$. Therefore, the risk that determines the final effects of cluster activity can have a positive or a negative dimension. Thus, contemporary clusters in various ways adjust their activities to the "double nature" of the risk. Whereas some of them still concentrate on continuous risk avoidance or minimization, others take risk intentionally, and entrepreneurially manage on the market. Ch. Richardson and M. Yamin suggest that the potential positive and negative impact of clustering on internationalization is characterized by ${ }^{23}$ :

- positive impact (e.g., the access to 'sticky' knowledge through cluster networks/relationships, observation/imitation, inter-firm labour mobility, access to specialized labour pools, access to industry - specific inter-mediate inputs and services, access to venture capitalists, technology spill-overs, association with cluster's 'brand name', higher chance of being 'found' by international contacts, etc.);

- negative impact (e.g., localized congestion, intense localized competition, distrust among the members, overdependence on region - specific resources, 'poaching' of workers by other cluster firms, loss of technological advantage due to imitation/technology spill-overs, etc.).

Additionally, cluster managers also underline that positive aspects of inter-cluster cooperation in international space include: greater strength in lobbying, co-promotion (promotion at the international level), the possibility of exchanging the information regarding cluster-based policies in different countries, forwarding obtained knowledge to local authorities and to other clusters, exchanging the experience and good practices ${ }^{24}$. The progressive development of clusters' international cooperation may also enable the access to

${ }^{21}$ M. Gancarczyk, Strategie internacjonalizacji przedsiębiorstw w klastrach [in:] Międzynarodowe stosunki gospodarcze - internacjonalizacja i konkurencyjność międzynarodowa, ed. T. Sporek, Wyd. Uniwersytetu Ekonomicznego w Katowicach, Katowice 2012, p. 132.

${ }^{22}$ F. Stremtan, S.S. Mihalache, V. Pioras, On the internationalization of the firms - from theory to practice, "Annales Universitatis Apulensis Series Oeconomica", Vol. 11, No. 2, 2009, p. 1030.

${ }^{23} \mathrm{Ch}$. Richardson, M. Yamin, The impact of industrial clusters on internationalization: the case of SMEs in Malaysia's Multimedia Super Corridor [in:] The process of internationalization in emerging SMEs and emerging economies, ed. H. Etemad, Edward Elgar Pub, Northampton 2013, p. 354.

${ }^{24} \mathrm{M}$. Bialic-Davendra, An investigation of a new concept of world-class clusters in Europe - a case study of the Visegrad Group of Countries, "Journal of Competitiveness", Issue 2, 2011, p. 53. 
specialized and advanced resources, intellectual capital (know-how, qualified work force, partnerships with key clients and/or suppliers), access to specialized, high quality services and infrastructure, to innovative branches in the industry in which cluster operates and also the proximity to competitors (which, e.g., influences pressure on innovations), etc. ${ }^{25}$. Moreover, A.S. Mikhailov considers that the formation of industrial clusters at an international level is an efficient mechanism for the innovative development of periphery regions of the countries involved in a cluster interaction ${ }^{26}$.

Industrial clusters comprise many resources (tangible and intangible resources) that cluster firms (mainly small and medium-sized companies) may leverage to initiate and accelerate their internationalization activities ${ }^{27}$. Cluster externalities have a positive impact on the internationalization process of the cluster firms and the reputation of cluster members. Cluster reputation assists the internationalization process of enterprises (mainly SMEs) in at least three ways: by reducing the legitimating expenses required by a new firm; by allowing a firm to charge premium prices and position itself on the higher end of its respective market; and by facilitating the finding (or the "being found") by current and future customers ${ }^{28}$.

On the basis of their own research, A. S. Mikhaylov and A. A. Mikhaylova indicate that the formation and the development of internationally organized clusters is a long and complex process that requires countries to have a strong innovative capacity, globally competitive economy, as well as a significant amount of annual investments in the sphere of science and education and for supporting international cluster initiative and international clusters that are already formed ${ }^{29}$. International cluster competitiveness is presently considered the key element of the maintenance and further development of global competitiveness of EU economy. Thus, various stakeholders undertake a number of initiatives to create the so-called meta-clusters by means of the fusion of clusters, to strengthen innovativeness and competitiveness of the entire EU economy, including national economies.

\section{3. 'BORN GLOBAL' TYPE OF CLUSTER INTERNATIONALIZATION}

The concept of a cluster of born global type is still a relatively new one, and has not been thoroughly discussed in economic literature. Clusters of born global type are defined taking into account the activity of a cluster as a certain entirety (organization) within the scope of internationalization, as well as taking into consideration the activity of entrepreneurs themselves (cluster members). A defining characteristic of a born global is its accelerated internationalization ${ }^{30}$. It ensues from the research conducted on cluster development that a number of clusters, particularly the innovative, high-tech and knowledgebased ones, fail to follow a typical path of gradual, evolutionary process of internationalization, as they initiate their activity on foreign markets right from the beginning of their existence. Frequently, the international or even global market is for them one of the major

\footnotetext{
${ }^{25}$ Ibidem, p. 44.

${ }^{26}$ A. Mikhailov, Development of international ..., op. cit., p. 37.

${ }^{27}$ D. Libaers, M. Meyer, Highly innovative small technology firms, industrial clusters and firm internationalization, "Research Policy" No. 40, 2011, p. 1427.

${ }^{28}$ D. McHardy Reid, R. DeMartino, S.C. Zyglidopoulos, The internationalization journey ..., op. cit., p. 544.

${ }^{29}$ A.S. Mikhaylov, A.A. Mikhaylova, Geographies of cluster ..., op. cit., p. 36.

${ }^{30}$ J. Weerawardena, G.S. Mort, P.W. Liesch, G. Knight, Conceptualizing accelerated internationalization in the born global firm: A dynamic capabilities perspective, "Journal of World Business", Vol. 42, 2007, p. 294.
} 
supply and sell markets. Sometimes, these clusters evince slightest or none interest in a national market. They specialize in manufacturing a certain product which distinguishes itself amidst the competition, and which is aimed at the sale on large, absorbent markets of highly developed countries. In the case of such clusters, high activity within the scope of internationalization is manifested by the members themselves, mainly entrepreneurs, who:

- initiated internationalization (including export and import activities) not later than 3 years after entering a national market and who are export-oriented - at least $10 \%$ of export ${ }^{31}$;

- by means of quick internationalization with substantial amount of international operations; they rest on various options to access sources, seek to found local advantages in host markets and monitor unique capabilities in order to create and coordinate value chains on international basis, become extensive export and/or import start-ups, become region specific businesses and global actors ${ }^{32}$;

- develop relatively fast on foreign markets and have exceptional skills, key competences in international business, which can be observed in the improvement of economic results right from the moment of their creation ${ }^{33}$;

- plan their businesses basing on global strategic perspectives; they look globally, and use global opportunities when suitable ${ }^{34}$.

It has to be emphasized that these entrepreneurs, owing to strategic cooperation within a business network (cluster), use common resources, including knowledge and experience of other partners. Thinking strategically, they efficiently use market chances, support the development of new, innovative goods and services, and actively take risk connected to entering new foreign markets. They continuously win new customers and acquire knowledge on new markets owing to the development of innovative ICT $^{35}$. Generally, it can be assumed that clusters of born global type are business organizations that:

- from inception, seek to derive significant competitive advantages from the use of resources and the sale of outputs in multiple countries ${ }^{36}$;

- have achieved international operations within a few years of its establishment through the application of knowledge-based resources to the sale of outputs in multiple countries and the combination of input resources from multiple countries, including those located beyond the firm's domestic continent ${ }^{37}$.

${ }^{31} \mathrm{~L} . \mathrm{Zhou}, \mathrm{W} . \mathrm{Wu}, \mathrm{X}$. Luo, Internationalization and the performance of born-global SMEs: the mediating role of social networks, "Journal of International Business Studies", Vol. 38, 2007, pp. 673-690.

${ }^{32}$ A. Gökmen, D. Temiz, Born global firms: a foreign trade related study on Turkey, "Eurasian Journal of Business and Economics", Vol. 6, No. 12, 2013, p. 130.

${ }^{33}$ G.A. Knight, S.T. Cavusgil, Innovation, organizational capabilities and the born-global firm, "Journal of International Business Studies", Vol. 35, 2004, pp. 124-141.

${ }^{34} \mathrm{~J} . \mathrm{S}$. Engel, I. del-Palacio, Global networks of clusters of innovation: accelerating the innovation process, "Business Horizons", Vol. 52, Issue 5, 2009, p. 497.

${ }^{35} \mathrm{~K}$. Przybylska, Born global: a new generation of small polish businesses, "Gospodarka Narodowa", No. 7-8, 2010, p. 71.

${ }^{36}$ B.M. Oviatt, P.P. McDougall, Toward a theory of international new ventures, "Journal of International Business Studies", Vol. 25, No. 1, 1994, p. 49.

${ }^{37} \mathrm{~L}$. Altshuler, Competitive capabilities of a technology born global, Lund Business Press, Lund Institute of Economic Research, Lund 2012, p. 29. 
From the viewpoint of the development strategy of this type of clusters, there can be observed a global orientation and high-level professionalism of cluster managers in international business right from the beginning of their existence. In clusters of born global type, the owners and managers of companies, leaders and cluster managers perceive world as a market without borders ${ }^{38}$. Contemporary possibilities of the development of European born global clusters are related, inter alia, to market openness and deregulation, the development of knowledge-based economy, the EU's orientation towards the development of economic networks, including knowledge transfer, technology and innovation in the competitive European area; and they constitute a new challenge within the scope of broader analysis of theoretical and practical dimension of cluster internationalization.

\section{CLUSTER INTERNATIONALIZATION - SELECTED RESULTS OF THE CLUSTER BENCHMARKING IN POLAND (EDITION 2014)}

The benchmarking of polish clusters is an example of cyclical research on the development of clusters in Poland and their internal transformation, which has already been conducted three times by the Polish Agency for Enterprise Development (PAED). It is an effective cluster policy tool which allows the identification of good practices in cluster management, the most effective methods for conducting joint operations within the cluster by comparing the activity of a particular cluster with others, including the model (benchmark) ones. The key objective of cluster benchmarking in Poland includes ${ }^{39}$ : providing clusters with a useful tool to improve their operations, gather knowledge and learn, demonstrating the best solutions and practices applied in polish clusters, indicating recommendations regarding cluster support policy to be implemented both on the country (central authorities) and regional/local level, providing recommendations for other entities that support clusters and cooperate with them, in particular R\&D institutions, innovation and enterprise support centers, collecting knowledge on the current cluster development stage in Poland and internal processes carried out in clusters, promoting the idea of clustering in Poland.

The first study of this kind was conducted in 2010 (on a sample of 47 clusters), the next in 2012 (a sample of 35 clusters) and 2014 (a sample of 35 clusters) ${ }^{40}$. In each edition

\footnotetext{
${ }^{38}$ G.A. Knight, S.T. Cavusgil, A taxonomy of born-global firms, "Management International Review", Vol. 43, Issue 3, 2005, p. 15.

${ }^{39}$ Deloitte Business Consulting, Benchmarking klastrów w Polsce - 2010. Raport z badania, PARP, Warszawa 2010, p. 210.

40 Third edition survey was conducted among 35 clusters based on a dedicated methodology developed in 2008 and then modified by a team of experts in 2010 and 2012. Out of this group, 31 clusters were involved in the 2012 survey and 20 in the 2010 survey. The clusters qualified for the study included mainly the ones which had participated in previous studies, and in particular in the second cluster benchmarking study carried out in 2012. The remaining 4 clusters which were to complement the sample were selected on the basis of the following criteria: specific form of business; concentration around a dominant industry and geographic concentration; durability of cooperation; involvement in common initiatives implementation of common projects and existence of common value chain links between enterprises/other entities operating in the cluster; diversity of entities making up the cluster (companies, representatives of the R\&D and academic sector, public authorities, support institutions); cluster having its own development strategy. Clusters have been benchmarked in four key areas: cluster resources, processes in a cluster, cluster performance, and growth potential, as well as 15 sub-areas in the framework of these areas. B. Plawgo, Benchmarking klastrów $w$ Polsce - edycja 2014. Raport z badania, PARP, Warszawa 2014, pp. 7-8; Deloitte Business Consulting, Benchmarking klastrów ..., op. cit., pp. 12-23, 114-120; J. Hołub, Benchmarking
} 
of the survey, the scale of assessment for particular areas/sub-areas was extensive (1-10, where 1 is the lowest rating and $10-$ the highest rating). The final assessment, based on an individual in-depth interview with cluster managers, was conducted via a standardized questionnaire by an expert in the field of clustering (a research team member).

One of the major sub-areas in the course of benchmarking studies was the level of cluster internationalization. In this sub-area the research had focused on the identification of standard parameters such as:

- the number of foreign markets (countries) on which cluster enterprises are present,

- the share of exports in the structure of sales in the cluster core,

- the number of formal cooperation agreements between the cluster and foreign entities.

Additionally, in 2010 that sub-area included also participation in trade fairs, international exhibitions, cluster's trade missions in the preceding 2 years and a number of publications in a foreign language (industry materials, press) in the preceding 2 years. The third edition of the survey in 2014, in addition to the three standard indicators, included the number of international networks/projects (thematic, industry-related) to which the cluster belongs.

Based on clusters' average results obtained in 2014 , in this sub-area one can conclude that the best rated were the shares of exports in the structure of sales in the cluster core (3.5 on average), slightly less rated: the number of foreign markets (countries) in which cluster enterprises are present ( 2.5 on average), the number of international networks/projects to which the cluster belongs ( 2.2 on average). Definitely, one of the major weaknesses of most of the surveyed clusters was their activity in the field of establishing formal cooperation agreements with foreign entities (only 0.5 on average). In the analyzed sub-area of cluster activity, it was easy to observe significant differences in the results of this activity. For example, in $2014^{41}$ :

- model (benchmark) cluster's enterprises operated on 100 markets, while the average for an individual cluster was 27 ;

- the maximum value of exports in the structure of sales was $90 \%$ (benchmark value), with the average for clusters at $35 \%$;

- model (benchmark) clusters had a total of 67 agreements concluded with clusters around the world, whereas an individual cluster in the sample concluded the average of nearly 5 agreements of this kind, 11 clusters at the time of the study failed to have a single contract concluded with a foreign entity;

- the surveyed clusters participated in a total of 68 networks/international projects, with an average of 2 , maximum - 8 , minimum - 0 (as many as 9 clusters).

It ensues from the results that the varied level of cluster internationalization may facilitate exchange of knowledge and experiences among cluster members on specific foreign markets, as well as contribute to a more active international expansion, especially of those clusters which have operated so far on a limited number of markets.

klastrów w Polsce - edycja 2012. Raport z badania, PARP, Warszawa 2012, pp. 13-18, 117-122; A. Nowakowska, Z. Przygodzki, M. Sokołowicz, J. Chądzyński, K. Matusiak, M. Klepka, Benchmarking klastrów: opracowanie i opis metodyki benchmarkingu klastrów w Polsce, PARP, Warszawa 2008.

${ }^{41}$ B. Plawgo, Benchmarking klastrów ..., op. cit., pp. 112-121. 
In the third edition of the survey in 2014 an essential complement to the research methodology was to obtain members' views of the surveyed clusters during ComputerAssisted Web Interviews (CAWI) and Computer Assisted Telephone Interviews (CATI). This survey aimed to evaluate the quality of cluster management and the ultimate effects of the functioning of these structures from the perspective of their members (mainly enterprises). The study involved 618 members selected form1917 members from all 35 Polish clusters surveyed.

For the assessment of the impact of cluster participation on cluster internationalization there were invited 513 selected entrepreneurs (representatives of 238 micro-, 143 small-, 91 medium-sized and 41 large enterprises). In this sample, there was noticed a very strong diversity of entities as to the business area. The quantitative majority of entities was engaged in both domestic and foreign markets (especially the EU). For 43 enterprises the main ones were the markets of EU members, and for 16 - foreign markets outside the EU. A vast majority of them assessed the coordinator's activity (cluster organization) very positively as to the support of the expansion of cluster enterprises to foreign markets, e.g. through the organization of trade missions, the transfer of information, participation in trade fairs abroad. Nearly $70 \%$ of the managers of the surveyed clusters considered the increase of the level of internationalization and international competitiveness of the cluster as a priority in terms of their strategic objectives for development. Moreover, during the study it was found that:

- $15 \%$ of respondents conducted research and developed in cooperation with foreign partners (non-members of the cluster);

- $37 \%$ of respondents participated in international economic events organized for the members of the cluster (e.g. trade fairs, exhibitions or other events);

- $32 \%$ of respondents felt that in the preceding two years they continued to introduce products/services into international markets;

- $28 \%$ of respondents gained new international markets in the preceding 2 years;

- $30 \%$ of respondents increased revenues from export.

These results indicate a moderate level of internationalization of the surveyed clusters. This certainly stems from the fact that, firstly, 8 of the surveyed clusters operated only from 2007, 7 - from 2008, 3 - from 2009, 3 - 2010, 7 - 2011, i.e. a vast majority of them had less than four-year experience in the operation on the market in a more or less formal structure. Secondly, the structure of cluster enterprises was dominated by microenterprises (44\%) and small businesses (32\%). Large enterprises, which generally have a wider range of activities on the domestic and international markets, accounted for only $6 \%$ in the analyzed structure of the enterprises within the surveyed clusters.

Not all participants expressed willingness to answer the question of whether participation in the cluster had positive influence on the introduction of another product/service into a foreign market. Of the 151 entrepreneurs who provided this reply, $59 \%$ felt that the influence was very small, while only $14 \%$ said it was large and very large. It was also difficult for the respondents to determine the influence of their current participation in the cluster on gaining new international markets. Of the 137 entrepreneurs who gave this reply, $62 \%$ felt that the impact was negligible, while only for $23 \%$ of them it was significant.

In most cases the respondents were not able to accurately assess the influence of participation in the cluster on the introduction of another product/service into the internation- 
al market, on attracting new foreign markets or increasing revenues from export activities. This area rated only approximately $30 \%$ among the respondents. The research shows that the more mutual are the projects within a cluster, the higher is also their activity on international markets and higher assessment of the impact of participation in a cluster on the process of internationalization. In addition, in this regard, the phase of cluster live cycles and size of the cluster were both important ${ }^{42}$ (Table 1).

Greater experience of clusters, associated with the growth/maturity phase translated into their much better performance in the respective ratios of internationalization. What is more, big clusters (over 61 members) operated on the largest number of foreign markets and in the largest number of international networks or projects in relation to other clusters. On the other hand, the managers of large clusters fail to show high activity in search for new foreign partners for cooperation (business environment institutions, clusters, etc.), which seems highly puzzling. Perhaps this is due to the fact that most of cluster managers first focused on the improvement of the internal processes in clusters, and only later on developing a network of relationships in the international areas.

Table 1. The average cluster internationalization rate depending on the number of members

\begin{tabular}{|l|c|c|c|}
\hline \multicolumn{1}{|c|}{ Factor } & Up to 28 members & 29-60 members & over 61 members \\
\hline $\begin{array}{l}\text { Number of foreign } \\
\text { markets (countries), on } \\
\text { which cluster enterprises } \\
\text { are present }\end{array}$ & 2,1 & 1,8 & 3,4 \\
\hline $\begin{array}{l}\text { Shareof exports in prod- } \\
\text { uct sales structure within } \\
\text { the cluster core }\end{array}$ & 4,2 & 3,0 & 3,6 \\
\hline $\begin{array}{l}\text { Number of international } \\
\text { networks/projects, in } \\
\text { which the cluster oper- } \\
\text { ates }\end{array}$ & 1,3 & 1,3 & 3,7 \\
\hline $\begin{array}{l}\text { Number of formal coop- } \\
\text { eration agreements } \\
\text { between the cluster and } \\
\text { foreign entities }\end{array}$ & 0 & 0,1 & 1,1 \\
\hline $\begin{array}{l}\text { Average for the sur- } \\
\text { veyed clusters }\end{array}$ & 1,7 & 1,4 & 2,7 \\
\hline
\end{tabular}

Source: own elaboration based on: B. Plawgo, Benchmarking klastrów ..., op. cit., pp. 119, 219-221.

The cluster internationalization is usually assessed in two aspects: firstly, in terms of the activity of cluster members in international markets, and, secondly, in terms of the activity of cluster coordinators on these markets, acting on behalf of the cluster. The research shows that a significant percentage of respondents fail to fully explore the opportu-

\footnotetext{
${ }^{42}$ In order for every group to be represented evenly two sections were created: 1-3 years and 4 years and more ("younger clusters" and "older clusters"). The first group was made up of 10 clusters whereas the

second one (4 years or more) consisted of 25 clusters. The assumed criterion allows to specify the level at which e.g. the experience in cooperation translates into the results achieved by a cluster. The phase of development criterion used in the previous edition of the benchmarking study (2012) was abandoned, since according to the rules of classification applied at that time all the clusters analyzed in this edition would get into one group (growth/maturity phase). B. Plawgo, Benchmarking klastrów ..., op. cit., p. 16.
} 
nities provided by the possibility of wider cooperation with clusters and other networks, operating in different parts of Europe and the world. Simultaneously, nearly half of respondents expect clusters and cluster organizations to develop activities for the sake of the expansion of cluster enterprises on foreign markets. Given that, clusters create an entrepreneurial ecosystem permanently stimulating their level of internationalization; what is also important are further improvements of cluster management processes.

\section{CONCLUSIONS}

One way to achieve higher degree of economic competitiveness is to increase the internationalization of enterprises. The fact that cluster internationalization becomes more and more significant ensues not only from the processes of globalization of the world economy and European Integration, but also from the fact that cluster structures constitute a successful means of attracting foreign investments.

The cluster internationalization occurs in two dimensions: the internationalization of the cluster as an organization and the internationalization of enterprises as cluster members. As mentioned before, there has been observed relatively high awareness of the need for internationalization at both levels. However, multiple factors affect the final actions undertaken on foreign markets and their effects. Potential benefits certainly include, among others, increase in sales, access to new markets, transfer of knowledge and knowhow, enhanced competitiveness. Nevertheless, one must note that the activity in the international markets is burdened with a number of restrictions and threats. This applies in particular to clusters where the dominant group members are SMEs. In their case, a significant limitation is, among others, the need for greater involvement of employees and financial resources. Those are necessary to establish business contacts and ensure active participation in the international project. In addition, there occur differences languageand culture-wise, as well as within knowledge of foreign markets and their legal and economic conditions.

The benchmarking of polish clusters conducted by the Polish Agency for Enterprise Development, as cyclical research on the development of clusters in Poland is an important policy tool which allows the identification of good practices in cluster management processes, including cluster internationalization. Based on clusters' average results obtained in 2014 one can conclude that the best rated were the shares of exports in the structure of sales in the cluster core, the number of foreign markets on which cluster enterprises are present and the number of international networks/projects to which a cluster belongs. The major weaknesses of most of the surveyed clusters were their activity in the field of establishing formal cooperation agreements with foreign entities. The results show that clusters' operating time and a higher number of their members have a positive impact on cluster internationalization, along with the percentage of large enterprises, which have better potential to move into foreign markets.

On the other hand, it should be noted that the presented study ignores the division of clusters into sectors, or even into product/service industries. Meanwhile, it may be an important factor in the development of internationalization, as research shows, because of the fact that service companies have a greater ability to cooperate on foreign markets, due to lower costs, greater mobility, and thus greater flexibility. On the other hand, industrial companies are more capital-intensive, whereas the cooperation with foreign partners is associated with, for instance, high transport costs, which further increases the risk in- 
volved. Therefore, the urgent need for internationalization of cluster enterprises is disproportionate to the state of understanding of the mechanisms and the effects arising from international cluster cooperation. To conclude, the concept of cluster internationalization is a relatively new issue in economics, therefore research in this area should be continued.

\section{REFERENCES}

[1] Altshuler L., Competitive capabilities of a technology born global, Lund Business Press, Lund Institute of Economic Research, Lund 2012.

[2] Andersen P.H., Regional clusters in a global world: production, relocation, innovation and industrial decline, "California Management Review", Vol. 49, Issue 1, 2006, pp. 101-122.

[3] Bialic-Davendra M., An investigation of a new concept of world-class clusters in Europe - a case study of the Visegrad Group of Countries, "Journal of Competitiveness", Issue 2, 2011, pp. 43-57.

[4] Colovic A., Lamotte O., The role of formal industry clusters in the internationalization of new ventures, "European Business Review", Vol. 26, Issue 5, 2014, pp. 449-470.

[5] Deloitte Business Consulting, Benchmarking klastrów w Polsce - 2010. Raport z badania, PARP, Warszawa 2010.

[6] Engel J.S., del-Palacio I., Global networks of clusters of innovation: accelerating the innovation process, "Business Horizons", Vol. 52, Issue 5, 2009, pp. 493-503.

[7] Gancarczyk M., Strategie internacjonalizacji przedsiębiorstw w klastrach [in:] Międzynarodowe stosunki gospodarcze - internacjonalizacja i konkurencyjność międzynarodowa, ed. T. Sporek, Wyd. Uniwersytetu Ekonomicznego w Katowicach, Katowice 2012, pp. 125-134.

[8] Gökmen A., Temiz D., Born global firms: a foreign trade related study on Turkey, "Eurasian Journal of Business and Economics", Vol. 6, No. 12, 2013, pp. 129-142.

[9] Greenhalgh B., Cluster internationalization handbook, Manchester Metropolitan University, Manchester 2012.

[10] Hołub-Iwan J., Benchmarking klastrów w Polsce - edycja 2012. Raport z badania, PARP, Warszawa 2012.

[11] Jankowska B., Internacjonalizacja klastrów, „Gospodarka Narodowa”, No. 5-6, 2010, pp. 1940.

[12] Knight G.A., Cavusgil S.T., Innovation, organizational capabilities and the born-global firm, "Journal of International Business Studies", Vol. 35, 2004, pp. 124-141.

[13] Knight G.A., Cavusgil S.T., A taxonomy of born-global firms, "Management International Review", Vol. 43, Issue 3, 2005, pp. 15-35.

[14] Kowalski A.M., The role of innovative clusters in the process of internationalization of firms, "Journal of Economics, Business and Management", Vol. 2, No. 3, 2014, pp. 181-185.

[15] Lämmer-Gamp T., Meier zu Köcker G., Christensen T., Clusters are individuals. Creating economic growth through cluster policies for cluster management excellence, The Danish Agency for Science Technology and Innovation, Copenhagen 2011.

[16] Libaers D., Meyer M., Highly innovative small technology firms, industrial clusters and firm internationalization, "Research Policy" No. 40, 2011.

[17] McHardy Reid D., DeMartino R., Zyglidopoulos S.C., The internationalization journey of a high-tech cluster, "Thunderbird International Business Review", Vol. 47, Issue 5, 2005.

[18] Mikhailov A.S, Development of international clusters in the Baltic Sea Region, "Baltic Region", No. 1, Vol. 15, 2013, pp. 37-46.

[19] Mikhaylov A.S., Mikhaylova A.A., Geographies of cluster internationalization: interorganizational linkages on the Baltica, "International Journal of Econometrics and Financial Management”, Vol. 3, No. 1, 2015, pp. 32-37.

[20] Nowakowska A., Przygodzki Z., Sokołowicz M., Chądzyński J., Matusiak K., KlepkaM.,Benchmarking klastrów: opracowanie i opis metodyki benchmarkingu klastrów w Polsce, PARP, Warszawa 2008. 
[21] Oviatt B.M., McDougall P.P., Toward a theory of international new ventures, "Journal of International Business Studies", Vol. 25, No. 1, 1994, pp. 45-64.

[22] Plawgo B., Benchmarking klastrów w Polsce - edycja 2014. Raport z badania, PARP, Warszawa 2014.

[23] Porter M.E., On Competiton, Harvard Business School Press, Cambridge 1998.

[24] Porter M.E., The economic performance of regions, "Regional Studies", Vol. 37, No. 6-7, August-October 2003, pp. 549-578.

[25] Porter M.E., Location, competition and economic development: local clusters in a global economy, "Economic Development Quarterly", Vol. 14, No.1, February 2000, pp. 15-34.

[26] Przybylska K., Proces internacjonalizacji przedsiębiorstwa w teorii ekonomicznej, Zeszyty Naukowe Wyższej Szkoły Ekonomicznej w Bochni, No. 3, Bochnia 2005, pp. 73-92.

[27] Przybylska K., Born global: a new generation of small polish businesses, "Gospodarka Narodowa", No. 7-8, 2010, pp. 63-84.

[28] Reid D., DeMartino R., Zyglidopoulos S.C., The internationalization journey of a high-tech cluster, "Thunderbird International Business Review", Vol. 47 (5), 2005, p. 529-554.

[29] Richardson Ch., Yamin M., The impact of industrial clusters on internationalization: the case of SMEs in Malaysia's Multimedia Super Corridor [in:] The process of internationalization in emerging SMEs and emerging economies, ed. H. Etemad, Edward Elgar Pub, Northampton 2013.

[30] Simmie J., The contribution of clustering to innovation: from Porter I agglomeration to Porter II export base theories [in:] Handbook of Research on Innovation and Clusters, Cases and Policies, ed. Ch. Karlsson, Edward Elgar Publishing Ltd, Northampton 2008.

[31] Stremtan F., Mihalache S.S., Pioras V., On the internationalization of the firms - from theory to practice, "Annales Universitatis Apulensis Series Oeconomica", Vol. 11, No. 2, 2009, pp. $1025-1033$

[32] Strukelj P., Dolinsek S., Internationalization of $R \& D$ in two high-tech clusters and cooperation of $R \& D$ units in those clusters, "Journal of Industrial Engineering and Management", No. 3, Vol. 2, 2010, pp. 294-308.

[33] Weerawardena J., Mort G.S., Liesch P.W., Knight G., Conceptualizing accelerated internationalization in the born global firm: A dynamic capabilities perspective, "Journal of World Business", Vol. 42, 2007, pp. 294-306.

[34] Zhou L., Wu W., Luo X., Internationalization and the performance of born-global SMEs: the mediating role of social networks, "Journal of International Business Studies", Vol. 38, 2007, pp. 673-690.

\section{INTERNACJONALIZACJA KLASTRA JAKO KLUCZOWY CZYNNIK DLA ROZWOJU I KONKURENCYJNOŚCI CZLONKÓW KLASTRA}

Umiędzynarodowienie klastra może pomóc przedsiębiorstwom, zwłaszcza MŚP w doskonaleniu ich konkurencyjności oraz przyspieszeniu ich obecności w globalnych łańcuchach wartości. Ten punkt widzenia jest często reprezentowany przez menedżerów zarządzających klastrami, naukowców i polityków. Jednak pilna potrzeba internacjonalizacji firm klastrów jest wciąż niewspółmierna w stosunku do stanu świadomości mechanizmów i skutków wynikających z międzynarodowej współpracy klastrów.

Pierwsza teoretyczna część tego artykułu zawiera przegląd literatury przedmiotu, który miał na celu ocenić stan wiedzy na temat umiędzynarodowienia klastrów, w tym przedsiębiorstw klastrów. Co ważne w tej części zaprezentowano m.in. nowy model klastrów tzw. klastry globalne od powstania, dla których internacjonalizacja jest główną strategią rozwoju. Empiryczna część artykułu opiera się na wynikach badań benchmarkingowych klastrów w Polsce, jakie były realizowane w 2014 roku. Autorzy podkreślają, że internacjonalizacja klastrów, w tym ich członków jest wciąż zagadnieniem nowym i złożonym, przez co wy- 
maga dalszych pogłębionych badań i analiz. Zrozumienie czynników, mechanizmów oraz finalnych efektów internacjonalizacji może pozwolić na lepsze dopasowanie instrumentów zarządzania klastrami i polityki klastrowej na poziomie regionalnym, jak i na poziomie Unii Europejskiej do potrzeb klastrów.

Słowa kluczowe: klaster, zarządzanie, strategia, internacjonalizacja, rozwój, konkurencyjność

DOI: 10.7862/rz.2015.mmr.52

Tekst złożono w redakcji: listopad 2015

Przyjęto do druku: styczeń 2016 